\title{
REFINEMENTS OF GENERALIZED HÖLDER'S INEQUALITY
}

\section{Jing-FEng TIAN AND Xi-Mei Hu}

Abstract. In this paper, we present some refinements of a generalized Hölder's inequality, which is due to Vasić and Pečarić.

Mathematics subject classification (2010): Primary 26D15; Secondary 26D10.

Keywords and phrases: Hölder's inequality, refinements, generalization.

\section{REFERENCES}

[1] S. Abramovich, J. PeČarić And S. Varošanec, Continuous sharpening of Hölder's and Minkowski's inequalities, Math. Inequal. Appl., 8, 2 (2005), 179-190.

[2] J. M. AldaZ, Self-improvement of the inequality between arithmetic and geometric means, J. Math. Inequal., 3, (2) (2009), 213-216.

[3] E. F. Beckenbach And R. Bellman, Inequalities, Springer-Verlag, Berlin, 1983.

[4] G. H. Hardy, J. E. Littlewood and G. Pólya, Inequalities, second ed., Cambridge University Press, UK, 1952.

[5] L. HoRVÁth AND J. PeČARIĆ, A refinement of the discrete Jensen's inequality, Math. Inequal. Appl., 14, 4 (2011), 777-791.

[6] M. Klaričić BakUla, A. Matković And J. PeČARIĆ, On the Jensen-Steffensen inequality for generalized convex functions, Period. Math. Hung., 55, 1 (2007), 19-34.

[7] J. MatKowsKi, A converse of the Hölder inequality theorem, Math. Inequal. Appl., 13, 1 (2009), 21-32.

[8] D. S. Mitrinović, J. E. PeČArić And A. M. Fink, Classical and New Inequalities in Analysis, Kluwer Academic, Dordrecht, 1993.

[9] D. S. Mitrinović And P. M. Vasić, Analytic Inequalities, Springer-Verlag, New York, 1970.

[10] P. M. VAsić, J. E. PeČARIĆ, On the Jensen inequality for monotone functions, An. Univ. Timişoara Ser. Şt. Matematice, 17 (1) (1979), 95-104. 